\title{
Full-scale tests on laterally loaded railway overhead line equipment mast foundations
}

\author{
DAVID J. RICHARDS*, WILLIAM POWRIE† and ANTHONY P. BLAKE $\$$
}

\begin{abstract}
Pile foundations for masts supporting overhead line equipment (OLE) on railways in Western Europe have traditionally been designed using empirical formulae derived from tests carried out in the 1950s under the auspices of the Union Internationale des Chemins de fer (UIC). Recent application in the UK of ostensibly more analytical approaches led to significantly increased pile lengths, which contributed to the high-profile cost over-run on the Great Western electrification programme. Further, the loads associated with some newer designs of mast are greater than those covered by the original field tests, and hence are outside the evidence base for the empirical approach. To address this, full-scale field tests were carried out on three, $610 \mathrm{~mm}$ dia. circular hollow-section steel piles installed in a railway embankment at the High Marnham test track (Nottinghamshire, UK). Each pile was designed according to the empirical OLE master index (OLEMI) method for a different form of modern OLE mast, and instrumented using Shape accelerometer arrays (SAAs) to determine pile deformations. The results provide valuable insights into the mechanisms of deformation of piles of different lengths, both at and beyond the expected in-service loads. $p-y$ curves derived from the SAA measurements compare reasonably well with curves constructed using the American Petroleum Institute method for undrained clay soils. The tests also demonstrate the suitability of the OLEMI approach for large structures and loads; and that the Eurocode 7 partial factors on load and undrained shear strength applied to an undrained (total stress) limit equilibrium calculation are likely to be sufficient to meet serviceability requirements for standard single-and twin-track cantilever structures.
\end{abstract}

KEYWORDS: design; field monitoring; field tests; foundations and soil-structure interaction; laterally loaded piles; pile foundations; physical modelling; transportation geotechnics

\begin{abstract}
INTRODUCTION
The estimated cost of the UK's Great Western mainline electrification project (GWEP) rose by $75 \%$ from $£ 1.6$ billion in 2014 to $£ 2 \cdot 8$ billion in 2016 (NAO, 2016). Part of the cost over-run related to the design and installation of the overhead line equipment (OLE; Fig. 1) - in particular, the foundation piles for the supporting structures (Powrie et al., 2019).

OLE support mast foundations, especially for cantilever structures, must resist potentially large lateral loads and moments at ground level, in addition to the vertical forces associated with the weight of the equipment they carry. On railways in the UK, OLE foundation piles have previously been designed using the OLE master index (OLEMI) method. OLEMI is a development by British Rail of an approach based on a series of empirical formulae derived from the results of reduced-scale model tests on square, rectangular and circular section piles in dry sand (Ramelot \& van Deperre, 1950), and
\end{abstract}

Manuscript received 27 August 2020; revised manuscript accepted 18 May 2021. Published online ahead of print 16 November 2021. Discussion on this paper closes on 1 July 2023, for further details see p. ii.

Published with permission by the ICE under the CC-BY 4.0 license. (http://creativecommons.org/licenses/by/4.0/)

$*$ School of Engineering, Faculty of Engineering and Physical Sciences, University of Southampton, Southampton, UK (Orcid:0000-0002-3819-7297).

$\uparrow$ School of Engineering, Faculty of Engineering and Physical Sciences, University of Southampton, Southampton, UK (Orcid:0000-0002-2271-0826).

† School of Engineering, Faculty of Engineering and Physical Sciences, University of Southampton, Southampton, UK

(Orcid:0000-0001-5718-7900).
233 full-scale field tests carried out in the 1950s under the auspices of the Office for Research and Experiments of the International Union of Railways (Union Internationale des Chemins de fer) (UIC-ORE, 1957). The field tests were carried out adjacent to railway lines, primarily on circular cylindrical concrete foundation piles with diameters ranging from $0.55 \mathrm{~m}$ to $1.2 \mathrm{~m}$ and lengths ranging from $1.2 \mathrm{~m}$ to $3.0 \mathrm{~m}$, in a range of soil types (mixed gravel, coarse gravels, sand and 'all kinds of clay') and various natural terrains (cutting, flat and embankment). Loading was characterised as either 'fast' (in which the moment limit was achieved in 15 min) or 'slow' (moment limit reached in weeks or some months).

The results of the tests revealed that the main factors affecting foundation performance were the dimensions of the foundation base, the ineffective depth of near-surface soil, the direction of pull in relation to the track, the distance of the stanchion from the track and the terrain type (cutting, level or embankment). Within the range tested, soil type was not found to be a key variable other than as characterised by the effective unit weight. Various empirical modification factors $(K)$ were derived from the tests, for application to the basic formulae to accommodate variations in the terrain type (cutting, embankment or level ground). The method is summarised in the Appendix to this paper and discussed in more detail by Powrie et al. (2019).

A review of Network Rail's experience of OLEMI-based design (Mootoosamy et al., 2015) highlighted its use in foundation allocation since 1984. In the electrification of the East Coast main line from Hitchin to Carstairs by way of Edinburgh in 1986-1992, OLEMI-based design was applied to both concrete and $610 \mathrm{~mm}$ dia. circular hollow-section (CHS) steel pile foundations supporting Mk3B $25 \mathrm{kV} \mathrm{AC}$ OLE system masts and equipment. It was also adopted on 


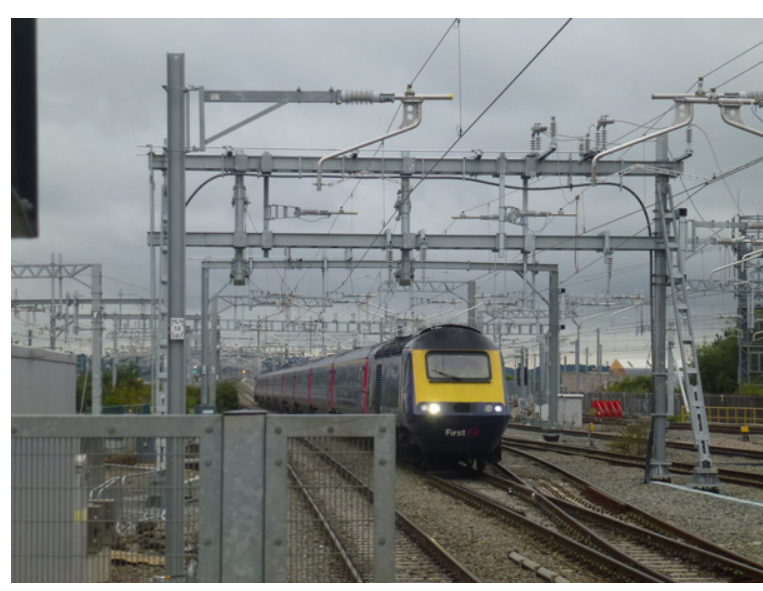

Fig. 1. Great Western electrification project OLE infrastructure at Reading

HS1 and has been used across the UK in ground conditions outside the original UIC-ORE test database including alluvium, chalk and, to a limited extent, peat.

More analytical design approaches (e.g. Atkins, 2010; Krechowiecki-Shaw \& Alobaidi, 2015) are generally based on limiting lateral stress distributions on a laterally loaded pile foundation originally proposed by Brinch (1961) or Broms (1964a, 1964b), possibly modified according to Fleming et al. (1994, 2009). In an ultimate limit state design using the partial factors on load or soil strength specified in Eurocode 7 (BSI, 2014a, 2014b), a limiting lateral stress approach can give results that are broadly comparable with OLEMI as long as the lateral earth pressure coefficients used take account of three-dimensional effects (Powrie et al., 2019). However, the use of plane-strain limiting lateral earth pressure coefficients in the calculation, or an attempt to carry out serviceability limit state checks using underestimated or inappropriate soil stiffness profiles, will lead to significantly less economic pile designs than those derived using OLEMI (Powrie et al., 2019).

Understanding the mode of pile behaviour is important in determining what influences the magnitude of pile head deflections. As demonstrated in this context by Powrie et al. (2019), in broad terms, the following points can be made.

(a) The deflection of a short, stiff pile, which rotates essentially as a rigid body about a point near the toe, depends mainly on the soil stiffness; halving the soil stiffness will roughly double the calculated pile head deflection.

(b) Conversely, the deflection primarily in bending of a pile long enough for its lower portion to be held essentially vertical by the soil, is in this case little affected by the soil stiffness.

(c) Increasing the pile length only reduces the pile head deflection if it changes the pile behaviour from 'short' (rigid body rotation about a point near the toe) to 'long' (deformation mainly in bending, with the lower portion remaining vertical)

The main factor militating against the use of OLEMI in determining pile lengths for the new Series 1 OLE structures used on GWEP was that, at the higher end, the associated loads were outside (greater than) those in the empirical evidence base that supports and justifies the use of the approach. This paper reports a series of full-scale field tests, carried out on piles installed in a railway embankment at the
Table 1. Characteristic (design or service) combinations of vertical and across- or along-track loads (horizontal and moment) associated with three types of Series 1 OLE structure (BH, 2015a, 2015b, 2015c)

\begin{tabular}{l|c|c|c}
\hline $\begin{array}{l}\text { Structure } \\
\text { type }\end{array}$ & $\begin{array}{c}\text { Permanent } \\
\text { moment: } \\
\mathrm{kNm}\end{array}$ & $\begin{array}{c}\text { Variable } \\
\text { moment 1 in 3 } \\
\text { year wind: } \\
\mathrm{kNm}\end{array}$ & $\begin{array}{c}\text { Variable } \\
\text { moment 1 in } \\
50 \text { year wind: } \\
\mathrm{kNm}\end{array}$ \\
\hline STC & $14 \cdot 9$ & $60 \cdot 2$ & $87 \cdot 5$ \\
TTC & 68.9 & 92.3 & 135.9 \\
XL-TTC & $193 \cdot 2$ & 183.3 & 251.9 \\
\hline
\end{tabular}

Network Rail High Marnham test track in Nottinghamshire, UK, to facilitate extension of the OLEMI design methodology to $610 \mathrm{~mm}$ dia. CHS steel piles and the high in-service loads associated with Series 1 OLE masts. Each pile was instrumented with Shape accelerometer arrays (SAAs) to measure deflections, from which $p-y$ curves were derived and compared with curves constructed using the undrained 'Clay API' method (API, 2014).

\section{DESIGN OF THE TEST PILES}

Each pile was designed according to the OLEMI principles for the loads associated with a different type of Series 1 OLE mast: a single-track cantilever (STC), a twin-track cantilever (TTC) and an extra-long twin track cantilever (XL-TTC). In all cases, the most onerous loading condition was in the direction towards the track. Characteristic (design or service) loads were calculated for these three structures by BH (2015a, 2015b, 2015c). Reflecting the OLEMI approach, loads are summarised as an equivalent moment at ground level, $M_{\mathrm{GL}}$ (as discussed in detail by Powrie et al. (2019)) in Table 1. Each structure must meet serviceability limits on variable-load deflection at the wire height under a 1 in 3 year wind load, but not under a 1 in 50 wind load, when the structure needs to meet only the ultimate limit state criterion (on the basis that trains would not be running in these conditions).

The required pile lengths were determined using the empirical equations given in UIC-ORE (1957), which are summarised in the Appendix. As in the OLEMI implementation, the weight of the foundation and structure was ignored $\left(N_{\mathrm{r}}=0\right)$; as explained by Powrie et al. (2019), this is a conservative simplification.

\section{THE TEST SITE}

The field tests were carried out on an embankment with a typical slope angle of $35^{\circ}$, on the Network Rail High Marnham test track near Boughton, Newark, UK (Ordnance Survey National Grid reference SK 67666 67690). A typical cross-section through the embankment is shown in Fig. 2.

To assess the geotechnical characteristics of the embankment in situ, piezocone tests were carried out 6 months prior to pile installation. At each test pile location, a $35.7 \mathrm{~mm}$ dia. cone (projected area $=10 \mathrm{~cm}^{2}$ ) was pushed into the ground at a rate of $20 \mathrm{~mm} / \mathrm{s}$ to a depth of $10 \mathrm{~m}$ below ground level. Profiles of piezocone end resistance, $q_{\mathrm{c}}$, sleeve friction resistance, $f_{\mathrm{s}}$, friction ratio, $R_{\mathrm{f}}$, pore water pressure, $u$, and undrained shear strength, $s_{\mathrm{u}}$, with depth (over the first $7 \mathrm{~m}$ of embedment) are shown in Fig. 3. $s_{\mathrm{u}}$ was estimated from $q_{\mathrm{c}}$ using equation (1)

$$
s_{\mathrm{u}}=\frac{\left(q_{\mathrm{c}}-\sigma_{\mathrm{v} 0}\right)}{N_{k}}
$$

where $\sigma_{\mathrm{v} 0}$ is the total vertical stress and $N_{k}$ is the empirical cone factor. $N_{k}$ was taken as 20 , which is towards the upper 


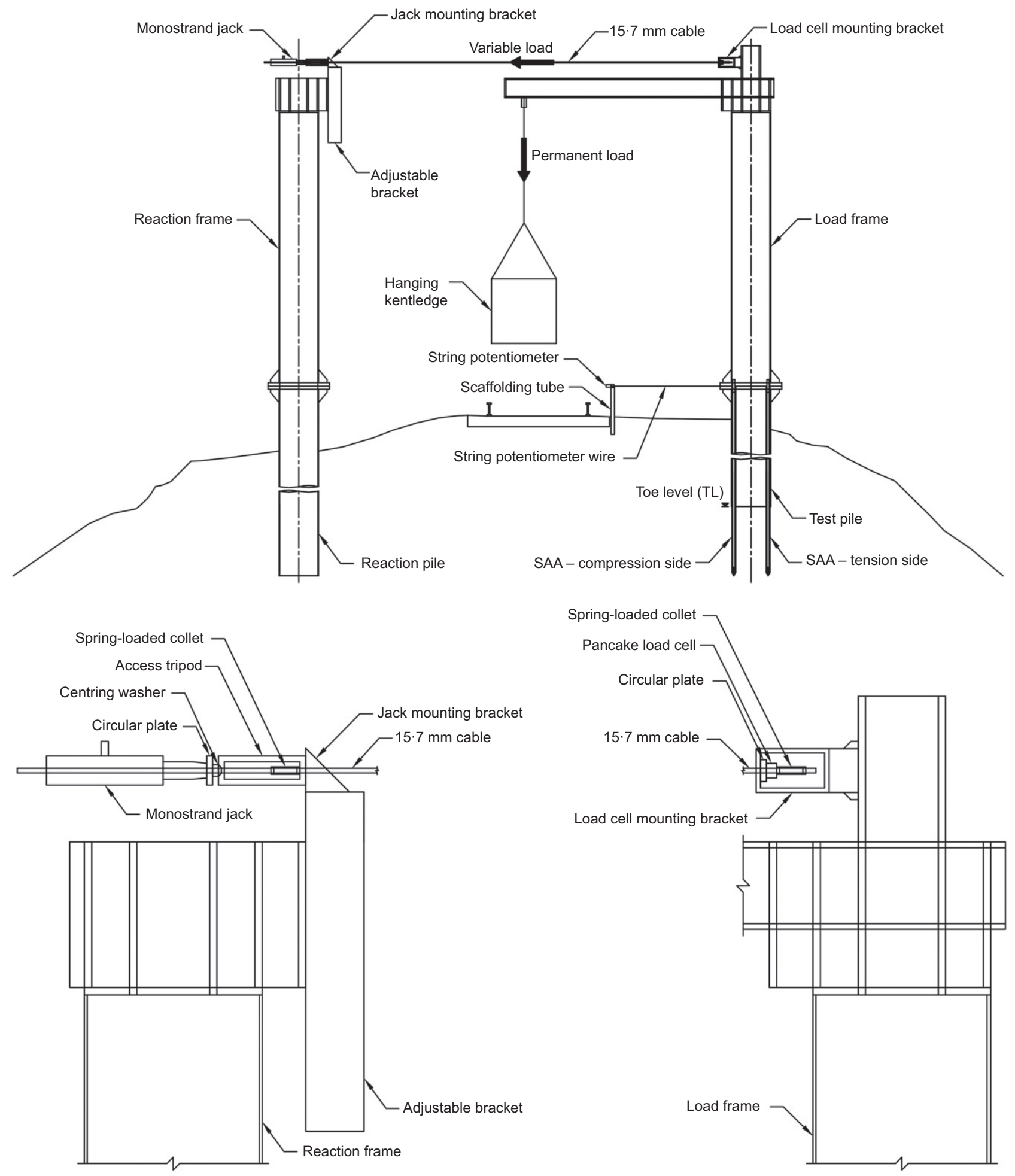

Fig. 2. Typical embankment cross-section and test arrangement. SAA, Shape accelerometer array

end of the range for glacial clays of 14 to 22 given by Meigh (1987). The $s_{\mathrm{u}}$ profiles were idealised as

$$
s_{\mathrm{u}}=s_{\mathrm{u}, 1}+k_{1} z \text { for } 0 \leq z \leq 2 \mathrm{~m}
$$

and

$$
s_{\mathrm{u}}=s_{\mathrm{u}, 2}+k_{2}\left(z-z_{1}\right) \text { for } 2 \leq z \leq 7 \mathrm{~m}
$$

where $s_{\mathrm{u}, 1}$ and $s_{\mathrm{u}, 2}$ are the undrained shear strengths at the top of the first and second soil layers, respectively; $k_{1}$ and $k_{2}$ are the undrained shear strength gradients of the first and second soil layers, respectively; and $z_{1}$ is the depth of the top soil layer. These parameters were taken as $s_{\mathrm{u}, 1}=0$, $s_{\mathrm{u}, 2}=140 \mathrm{kPa}, k_{1}=70 \mathrm{kPa} / \mathrm{m}, k_{2}=10 \mathrm{kPa} / \mathrm{m}$ and $z_{1}=2 \mathrm{~m}$. The resulting idealised $s_{\mathrm{u}}$ profile is shown in Fig. 3(e).

Adoption of the cone penetration test (CPT)-based soil behaviour type classification system (Robertson et al., 1986; Robertson, 1990, 2009, 2016) indicated that the soil stratigraphy varies across the test site, with two predominant soil types present: (a) medium-dense locally loose sand to 


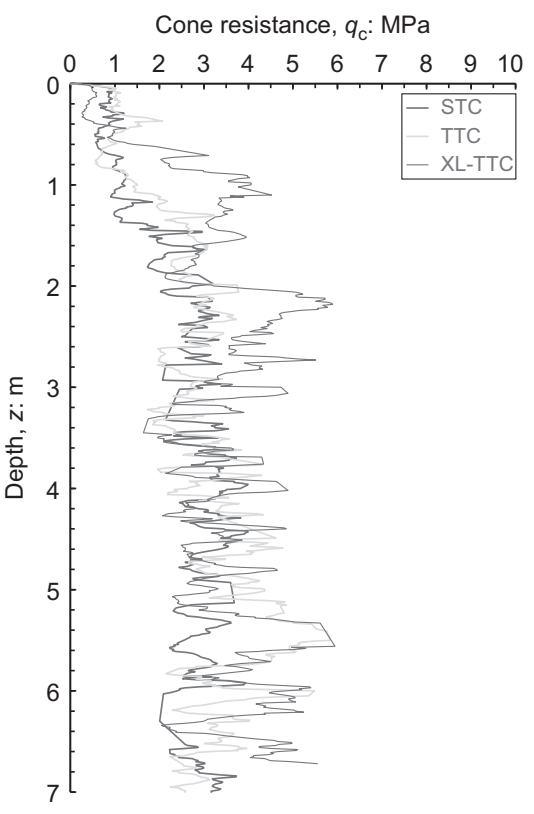

(a)

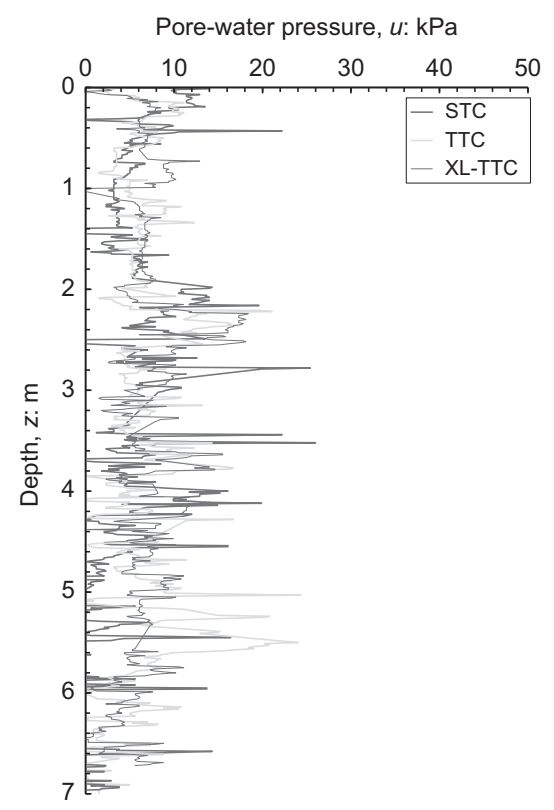

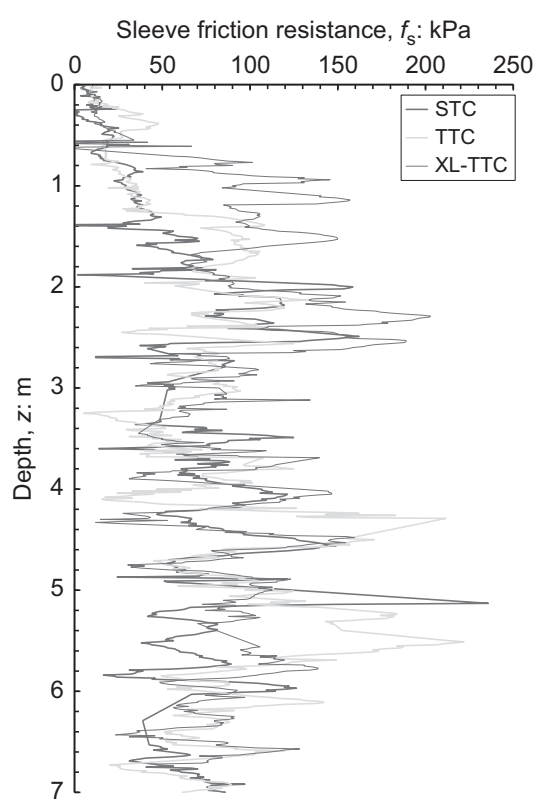

(b)

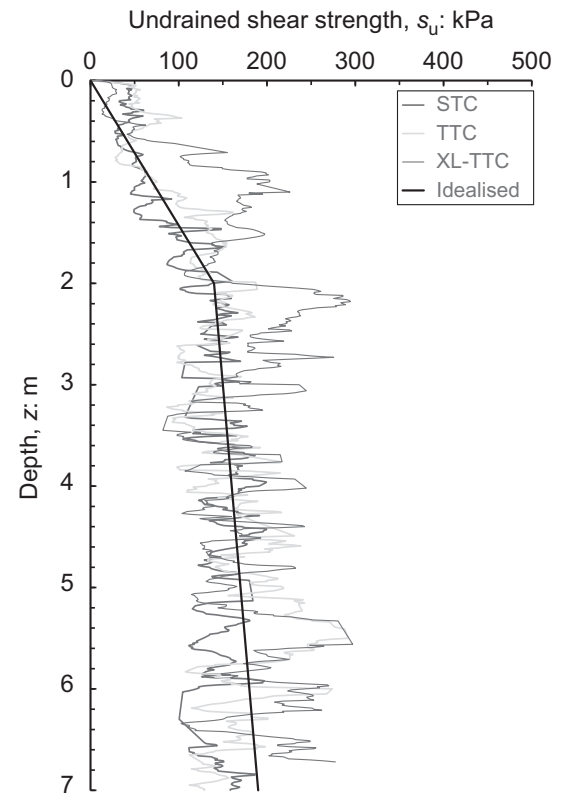

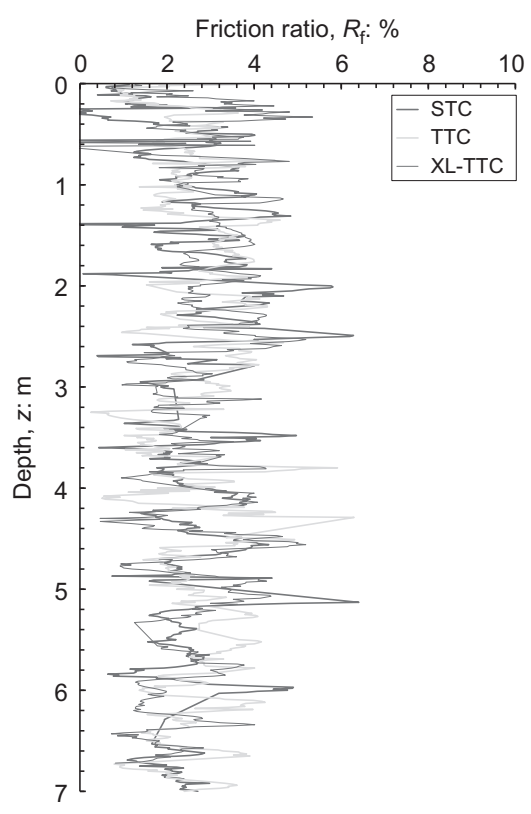

(c)

Fig. 3. Profiles of: (a) piezocone end resistance, $q_{\mathrm{c}}$; (b) sleeve friction resistance, $f_{\mathrm{s}}$; (c) friction ratio, $R_{\mathrm{f}}$; (d) pore-water pressure, $u$; (e) undrained shear strength, $s_{\mathrm{u}}$

silty sand; (b) medium-strength to high-strength sandy silt to clayey silt. The piezocone tests showed no significant in situ pore-water pressure, indicating that the water table was at least $10 \mathrm{~m}$ below ground level.

Characterisation and index tests carried out in accordance with BS 1377 (BSI, 2016) using density rings and fall cone apparatus on the finer, predominant stratum identified it as a 'firm to very stiff reddish brown clayey silt'. Triaxial testing was carried out on samples recovered from 6 to $6.5 \mathrm{~m}$ below ground level using an electromechanical displacementcontrolled triaxial frame and a standard triaxial cell. Specimens were $38 \mathrm{~mm}$ in diameter and $76 \mathrm{~mm}$ high and were locally instrumented with a single submersible linear variable differential transducer (LVDT) to measure radial strain. The specimen was saturated by increasing the back-pressure and the cell pressure in parallel in accordance with BS1377, until a $B$ value of 0.96 was achieved. The specimen was $K_{0}$ consolidated (with the cell pressure increased to maintain zero lateral strain as measured using the radial instrumentation) to the estimated in situ condition $\left(K_{0}\right.$ in the range $\left.0 \cdot 4-0 \cdot 45\right)$. The specimen was then subjected to undrained, strain-controlled shear to failure. The critical state angle of shearing resistance, relevant to the ultimate limit state of a laterally loaded pile, was determined from data at the end of the shear test when the specimen was continuing to deform at constant stress ratio and specific volume, as $\phi_{\text {crit }}^{\prime}=40^{\circ}$. The smallstrain shear modulus, measured using bender elements, was $G_{\mathrm{vh}}=60 \mathrm{MPa}$. Index test and in situ density data are summarised in Table 2.

\section{INSTALLATION OF TEST PILES AND INSTRUMENTATION}

Three $610 \times 10 \mathrm{~mm}$ CHS steel test piles were fabricated, with design embedment lengths (derived from the OLEMI 
method) of $3.16 \mathrm{~m} \mathrm{(STC),} 4.33 \mathrm{~m} \mathrm{(TTC)}$ and $6.23 \mathrm{~m}$ (XL-TTC) with three $610 \times 16 \mathrm{~mm}$ CHS reaction piles, of lengths $5.7 \mathrm{~m}$ (STC), $6.9 \mathrm{~m}$ (TTC) and $8.8 \mathrm{~m}$ (XL-TTC). All piles had an additional upstand of $0.5 \mathrm{~m}$ above ground level to facilitate disconnection of the pile driving head. Steel grade BSS355J0 was used for all piles.

The test and reaction piles were driven to their design depths by vibration and hammering, using a road-rail vehicle mounted Movax high-frequency vibratory-type pile driver to design or refusal depth. If refusal was encountered, a Fambo hydraulic impact-type piling hammer was employed to achieve the design depth.

The test piles were instrumented with removable SAAs to measure pile deflections, from which $p-y$ curves could be derived. The SAAs comprised a chain of $200 \mathrm{~mm}$ long rigid segments separated by flexible joints. Each segment contained a three-axis micro-electromechanical system (MEMS) accelerometer that measured segment tilt, enabling overall

Table 2. Properties of the firm to very stiff reddish brown clayey silt within the embankment

\begin{tabular}{l|l}
\hline Property & Value \\
\hline In situ bulk unit weight, $\gamma_{\text {bulk }}$ & $18 \cdot 75$ to $19 \cdot 58 \mathrm{kN} / \mathrm{m}^{3}$ \\
In situ water content, $w$ & $11 \cdot 83$ to $12 \cdot 10 \%$ \\
In situ dry unit weight, $\gamma_{\text {dry }}$ & $16 \cdot 09$ to $17 \cdot 16 \mathrm{kN} / \mathrm{m}^{3}$ \\
Liquid limit, $w_{\mathrm{LL}}$ & $32 \%$ \\
Plastic limit, $w_{\mathrm{PL}}$ & $16 \cdot 5 \%$ \\
Plasticity index, PI & $15 \cdot 5 \%$ \\
Critical state angle of & $40^{\circ}$ \\
$\quad$ shearing resistance, $\phi_{\text {crit }}^{\prime}$ & $60 \mathrm{MPa}$ \\
Small-strain shear modulus, $G_{\mathrm{vh}}$ & \\
\hline
\end{tabular}

deformations to be derived. SAAs were positioned on both the compression and tension sides of the test piles, housed within $27 \mathrm{~mm}$ dia. unplasticised polyvinyl chloride (uPVC) conduit grouted into $60.3 \times 3.0 \mathrm{~mm}$ CHS tubes welded to the inside face of the test piles (Fig. 4). Each SAA was interfaced using a field power unit. Data were sampled at a rate of 100 samples per second and averaged over a period of $10 \mathrm{~s}$ on a field laptop using the software package SAA Recorder, which derived pile deformations in real time from the accelerometer tilt measurements.

Determining pile deformations from SAA measurements requires the absolute location of one point to be known. It is often assumed that the pile toe remains fixed, but this is not a suitable assumption for 'short' piles that deform primarily by rigid body rotation about a point above the toe. A system was therefore developed to extend the SAAs to a distance of approximately $1 \mathrm{~m}$ below the pile toe to provide a fixed point of reference for the device (Fig. 4(a)). A sacrificial (dummy) steel cone (Fig. 4(b)), retained by O-ring seals, was inserted into the toe end of the $60.3 \times 3 \mathrm{~mm}$ CHS SAA housing (Fig. 4(a)), which had been tack-welded to the inside of the CHS pile section along its full length, to prevent soil ingress during pile driving. The dummy cones were fabricated to accept a custom-made pushrod, which connected with a standard $36 \mathrm{~mm}$ dia. CPT rod. Following piling, a road-rail vehicle mounted CPT rig was used to drive the pushrod into the SAA housing until it engaged with the dummy cone. The dummy cone was then driven to a target embedment of $1 \mathrm{~m}$ depth below the pile toe $(0 \cdot 82$ to $1 \mathrm{~m}$ achieved), forming a void within the soil to receive the SAA (Fig. 4(c)). The pushrod was recovered and the void sleeved to prevent infilling during adjacent pile installation works before SAA uPVC tubular housings were installed to depth and grouted into place.

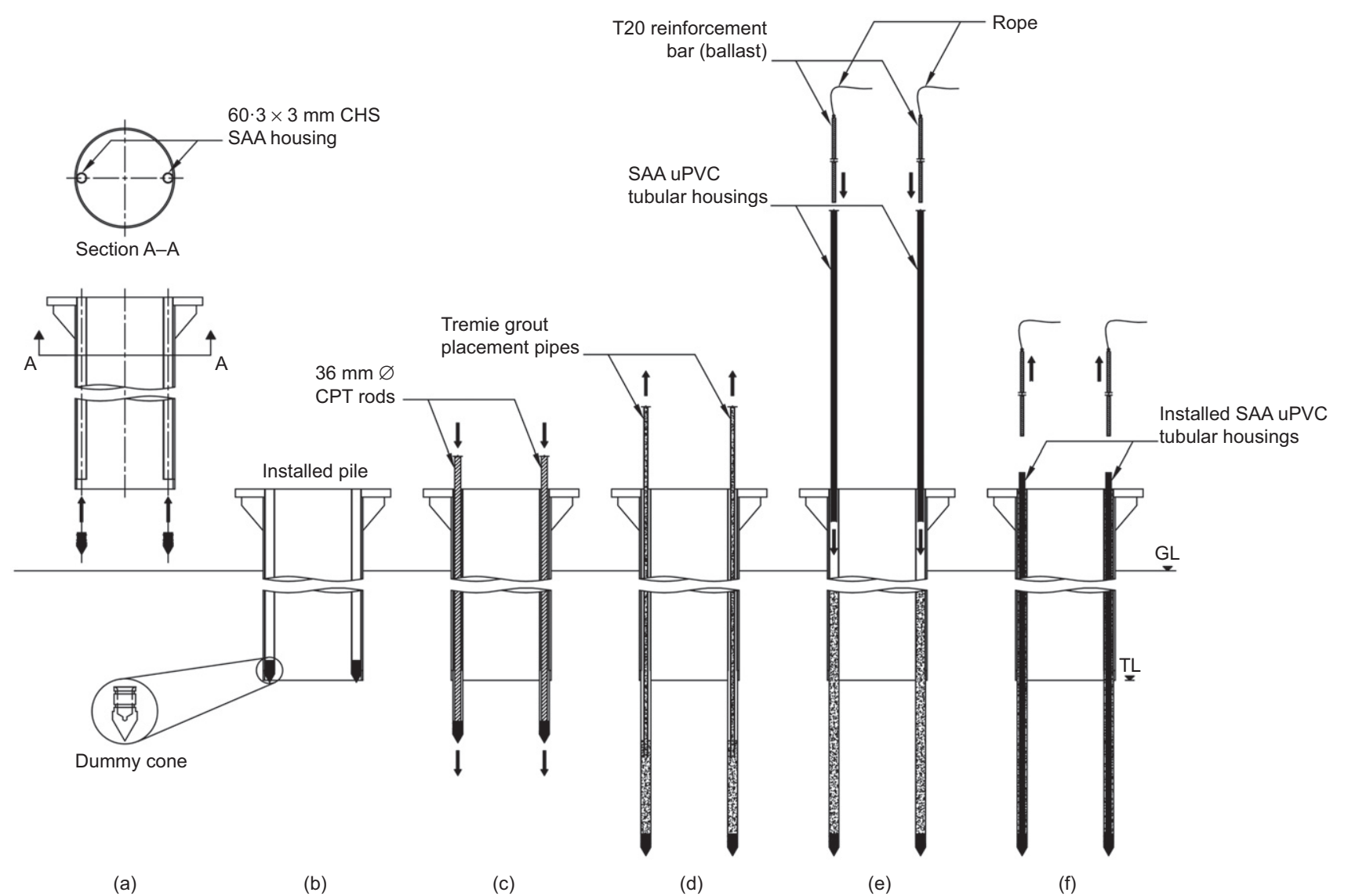

Fig. 4. Shape accelerometer array (SAA) installation 
After the SAA housings had been installed, they were filled with predetermined volumes of Parex cable grout (TG108), pumped into each housing using a diaphragm hand pump (Fig. 4(d)). This grout was selected for its relatively low viscosity, low shrinkage, high strength, high stiffness and rapid hardening rate compared with traditionally adopted grout mixes for borehole instrumentation. Preassembled uPVC SAA conduit was then submerged into the grout (Fig. 4(e)). Lengths of T20 reinforcement bar were lowered into the conduit by a rope fastened to a lifting eye, to offset the buoyancy effects of submergence in fresh grout. The grout rapidly hardened (with minimum shrinkage), effectively coupling the SAA housing and thereby the SAA with the pile (Fig. 4(e)). This SAA installation method was trialled in the laboratory before deployment in the field and is illustrated in Fig. 4.

A string potentiometer was used to measure the lateral deflections at the pile head level $(0.5 \mathrm{~m}$ above ground level) during loading, providing verification of the SAA measurements. The sensor was a Measurements Specialities SP-1-50 with an accuracy of $\pm 0 \cdot 25 \%$, quasi-infinite resolution (determined by the data logger) and a stroke of $1.270 \mathrm{~m}$. The string potentiometer was mounted on horizontal scaffolding tubes supported by vertical posts, driven into the soil at a distance of $3 \cdot 5$ pile diameters $(2 \cdot 135 \mathrm{~m})$ from the centre of the test pile to ensure the sensor remained remote from any pile movement.

\section{SEQUENCE OF TESTING}

The tests were designed to determine both the deflection of the foundation at working loads and the ultimate foundation capacity. Further benefits would include data on pile deformation mechanisms at various stages of loading, and on the development of the pressure-displacement $(p-y)$ relationships at various depths. The loading schedule was specified in accordance with BS EN 61773: 1997, IEC 61773: 1996 Overhead lines - testing of foundations for structures (BSI, 1997), and comprised three distinct stages, as described below.

(a) Stage 1: (100\% permanent load $)+(0$ to $100 \%$ of the variable load associated with a 1 in 3 year wind), with a full loading-unloading cycle to measure any permanent set of the foundation.

(b) Stage 2: (100\% permanent load $)+(0$ to $100 \%$ of the variable load associated with a 1 in 50 year wind).

(c) Stage 3: $(100 \%$ permanent load $)+($ an increase in the variable load until the full capacity of the foundation (onset of failure) was reached).

Within each stage, the loads were applied in discrete steps. Permanent (vertical) loads were applied using a hanging kentledge from a boom attached to the test structure (Fig. 2).
A $1 \mathrm{~m}^{3}$ water bowser was used as kentledge for the STC test, and steel weights for the TTC and XL-TTC tests. The test arrangement is shown in Fig. 2 and the loading arrangement is summarised in Table 3.

Variable (lateral) loading was applied incrementally using a single-acting spring-loaded return monostrand jack (of $10 \mathrm{t}$ capacity for stages 1 and 2, and 25 t capacity for stage 3 ), energised by a hand pump. The jack reacted against a mounting bracket at the top of the reaction frame through a circular plate, centring washer and access tripod. The jacking load was transferred to the test piles by way of a $15.7 \mathrm{~mm}$, seven-strand pre-stressing cable with a guaranteed ultimate tensile strength of $279 \mathrm{kN}$. The cable passed through a spring-loaded collet housed within the access tripod; the collet was tightened to hold the cable and maintain the load during resetting or swapping the jacks. The cable passed through a load cell mounting bracket (made from $200 \mathrm{~mm} \times 300 \mathrm{~mm}$ rectangular hollow-section steel) positioned at the top of the loading frame, a circular plate, a pancake load cell and a spring-loaded collet. This collet was tightened onto the cable throughout the load application, reacting against the load cell mounting bracket through the load cell and circular plate.

The load was kept constant at the end of each load step, until the rate of pile movement was less than $0 \cdot 2 \mathrm{~mm} / \mathrm{min}$. Failure was considered to have occurred if the pile movement remained in excess of $0.2 \mathrm{~mm} / \mathrm{min}$ for more than $3 \mathrm{~min}$ (i.e. if the pile had not stabilised within $3 \mathrm{~min}$ of increasing the load), as specified in BS EN 61773 (BSI, 1997).

\section{RESULTS AND DISCUSSION}

\section{Pile moment-displacement measurements}

The pile moment-displacement responses for each test pile are shown in Fig. 5. The load is expressed in terms of moment at ground level, $M_{\mathrm{GL}}$, and includes both the permanent and variable load components. Permanent loads applied to the test piles were $14.9 \mathrm{kNm}$ (STC), $68.9 \mathrm{kNm}$ (TTC) and 193.2 kNm (XL-TTC).

Displacements at ground level and moments associated with $(a)$ the permanent load, plus $(b)$ the 1 in 3 year wind load and $(c)$ the 1 in 50 year wind load, as well as $(d)$ the onset of failure are summarised in Table 4.

Figure 6 shows the deflected shape of each test pile, as measured by the SAAs, at the 1 in 3 year wind load, 1 in 50 year wind load and onset of failure. Pile deflections and rotations increase with increasing applied moment, as would be expected. The STC pile is effectively 'short', deforming at all load stages primarily by rigid body rotation with relatively little bending. The point of rotation of the pile moves gradually upward as the moment is increased. The TTC pile shows much less movement of the toe during the first two stages of loading, and generally more noticeable bending deflections. The XL-TTC is 'long'; in the first two stages of loading, deflection is mainly by bending, with the toe of the

Table 3. Loading arrangement

\begin{tabular}{l|l|l|l|l|l|l|l}
\hline \multirow{2}{*}{ Structure type } & \multicolumn{3}{|c|}{ Permanent (vertical) load } & \multicolumn{3}{c}{ Variable (horizontal) load } \\
\cline { 2 - 8 } & $\begin{array}{l}\text { Eccentricity } \\
\text { of load frame } \\
\text { boom: } \mathrm{m}\end{array}$ & $\begin{array}{l}\text { Load } \\
\text { frame } \\
\text { boom: } \mathrm{kN}\end{array}$ & $\begin{array}{l}\text { Eccentricity } \\
\text { of kentledge: } \\
\mathrm{m}\end{array}$ & $\begin{array}{l}\text { Kentledge: } \\
\mathrm{kN}\end{array}$ & $\begin{array}{l}\text { Height of action } \\
\text { of lateral load above } \\
\text { ground level: } \mathrm{m}\end{array}$ & $\begin{array}{l}\text { Lateral load } \\
1 \text { in } 3 \text { year } \\
\text { wind: } \mathrm{kN}\end{array}$ & $\begin{array}{l}\text { Lateral load } \\
1 \text { in } 50 \text { year } \\
\text { wind: } \mathrm{kN}\end{array}$ \\
\hline STC & $1 \cdot 824$ & $1 \cdot 66$ & $3 \cdot 599$ & $3 \cdot 28$ & $4 \cdot 584$ & $13 \cdot 13$ & $19 \cdot 09$ \\
TTC & $2 \cdot 0$ & $3 \cdot 37$ & $3 \cdot 647$ & $17 \cdot 05$ & $5 \cdot 584$ & $3 \cdot 53$ & $24 \cdot 34$ \\
XL-TTC & $2 \cdot 0$ & $3 \cdot 37$ & $3 \cdot 647$ & $51 \cdot 13$ & $5 \cdot 672$ & $32 \cdot 32$ & $44 \cdot 41$ \\
\hline
\end{tabular}




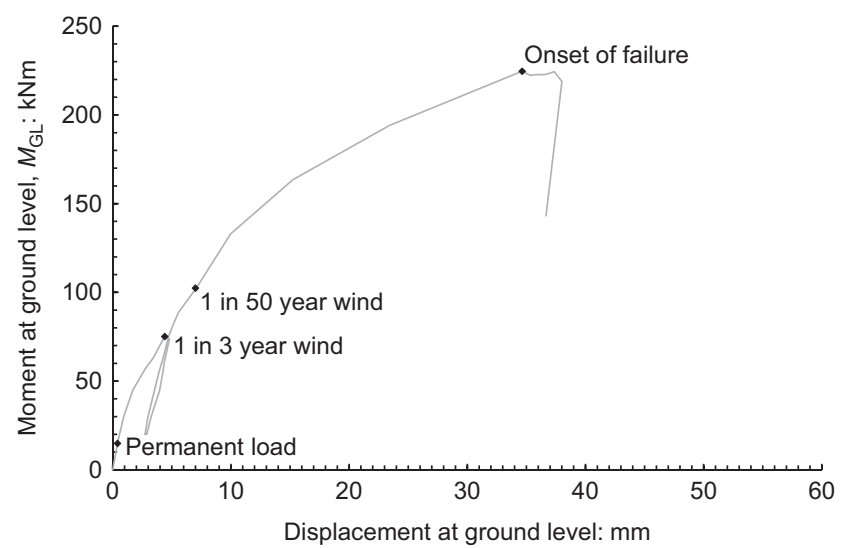

(a)

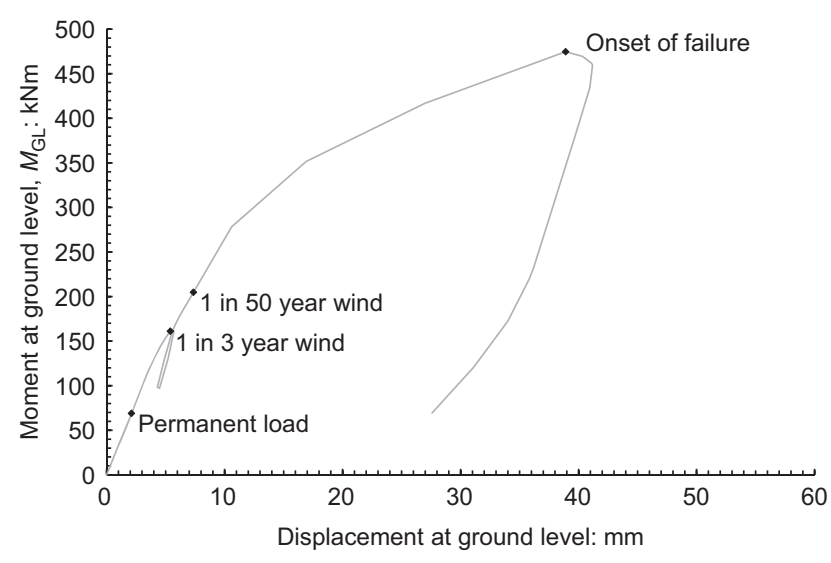

(b)

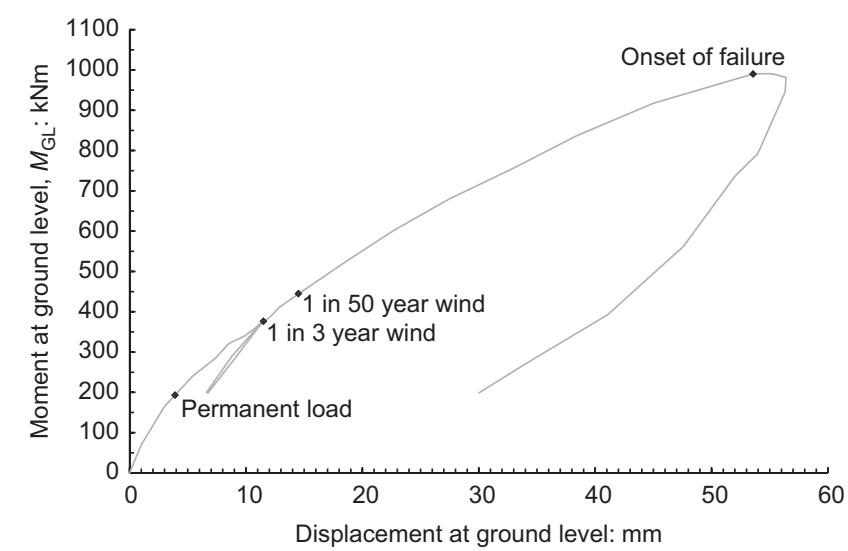

(c)

Fig. 5. Pile moment-displacement response: (a) single-track cantilever (STC); (b) twin-track cantilever (TTC); (c) extra-long twin-track cantilever (XL-TTC)

Table 4. Displacements at ground level and moments associated with (a) the permanent load, (b) plus the 1 in 3 year wind load, and (c) the 1 in 50 year wind load, and (d) the onset of failure

\begin{tabular}{|c|c|c|c|c|c|c|c|c|}
\hline \multirow[t]{2}{*}{ Test pile } & \multicolumn{2}{|c|}{ Permanent load } & \multicolumn{2}{|c|}{1 in 3 year wind } & \multicolumn{2}{|c|}{1 in 50 year wind } & \multicolumn{2}{|c|}{ Onset of failure } \\
\hline & $\begin{array}{l}\text { Moment: } \\
\text { kNm }\end{array}$ & $\begin{array}{l}\text { Displacement } \\
\text { at ground } \\
\text { level: } \mathrm{mm}\end{array}$ & $\begin{array}{l}\text { Moment: } \\
\text { kNm }\end{array}$ & $\begin{array}{l}\text { Displacement } \\
\text { at ground } \\
\text { level: } \mathrm{mm}\end{array}$ & $\begin{array}{l}\text { Moment: } \\
\text { kNm }\end{array}$ & $\begin{array}{l}\text { Displacement } \\
\text { at ground } \\
\text { level: } \mathrm{mm}\end{array}$ & $\begin{array}{l}\text { Moment: } \\
\text { kNm }\end{array}$ & $\begin{array}{l}\text { Displacement } \\
\text { at ground } \\
\text { level: mm }\end{array}$ \\
\hline STC & $14 \cdot 9$ & $0 \cdot 4$ & $75 \cdot 1$ & $4 \cdot 4$ & $102 \cdot 4$ & $7 \cdot 0$ & $224 \cdot 6$ & $34 \cdot 6$ \\
\hline TTC & $68 \cdot 9$ & $2 \cdot 1$ & $161 \cdot 2$ & $5 \cdot 4$ & $204 \cdot 8$ & $7 \cdot 4$ & $474 \cdot 7$ & $38 \cdot 9$ \\
\hline
\end{tabular}

pile remaining fixed in terms of both rotation and deflection. However, at the maximum load, the XL-TTC pile shows significant rotation about a point some $4.5 \mathrm{~m}$ below ground level, with bending deflections superimposed.

\section{Pile moment capacity}

Figure 7 shows the moment-deflection response for all three piles, expressed as a percentage of the OLEMI design load. The STC, TTC and XL-TTC piles reached ultimate capacities of $2 \cdot 19,2 \cdot 32$ and $2 \cdot 22$ times the OLEMI design or characteristic load ( 1 in 50 year wind load), respectively.

The moment-displacement plots indicate up to about $2 \cdot 7$ (STC), 4.5 (TTC) and $6.6 \mathrm{~mm}$ (XL-TTC) of irrecoverable lateral pile head displacement at the 1 in 3 year wind load on first loading, with essentially elastic (recoverable) behaviour on unloading from and reloading to this point. The increments of pile head rotation and lateral deflection on first reaching the 1 in 3 year wind load (excluding the permanent load component) would translate to across track wire height ( $5 \cdot 2 \mathrm{~m}$ above pile head) deflections of 13.5 (STC), 14.4 (TTC) and $30 \mathrm{~mm}$ (XL-TTC), which are less than the limit of $50 \mathrm{~mm}$ specified in Network Rail standard NR/SP/ELP/27215 (Network Rail, 2004). On the one hand, the calculated deflection does not include the effect of the deformation of the above-ground structure, but on the other hand it does include some irrecoverable foundation displacement from first loading that could be compensated for by re-setting the catenary. It therefore seems likely that the OLEMI approach would satisfy the serviceability limit state requirement for all three structures, with a lumped factor of about $2 \cdot 19$ on the total load.

Eurocode 7 requires partial factors of 1.3 on unfavourable variable loads and $1 \cdot 25$ (for $\tan \phi^{\prime}$ ) or $1 \cdot 4$ (for $s_{\mathrm{u}}$ ) on soil 


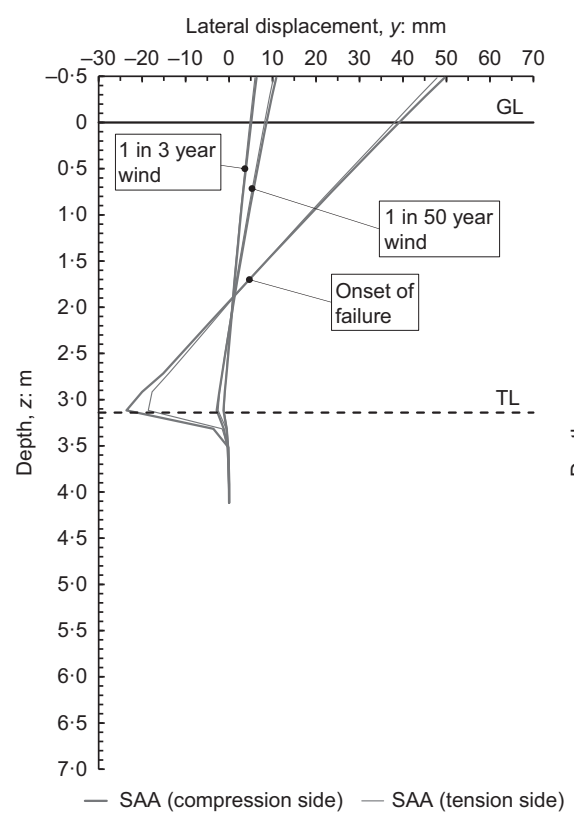

(a)

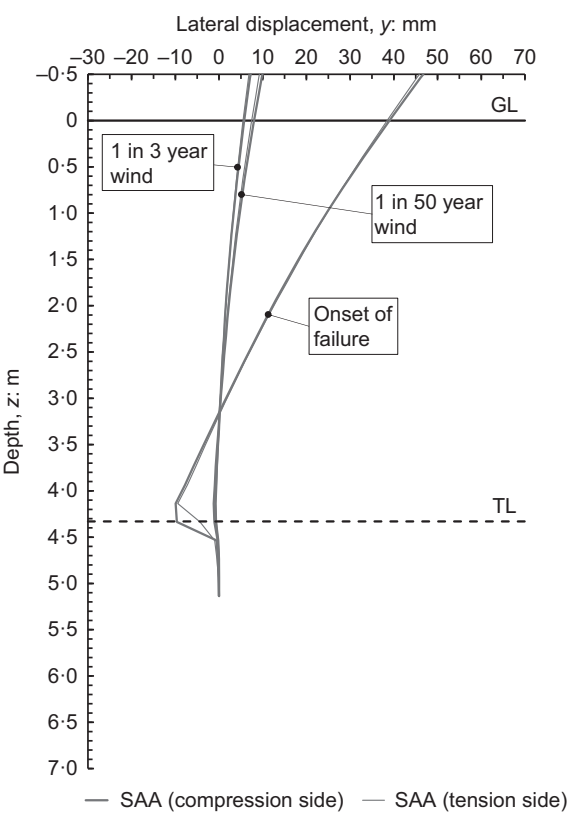

(b)

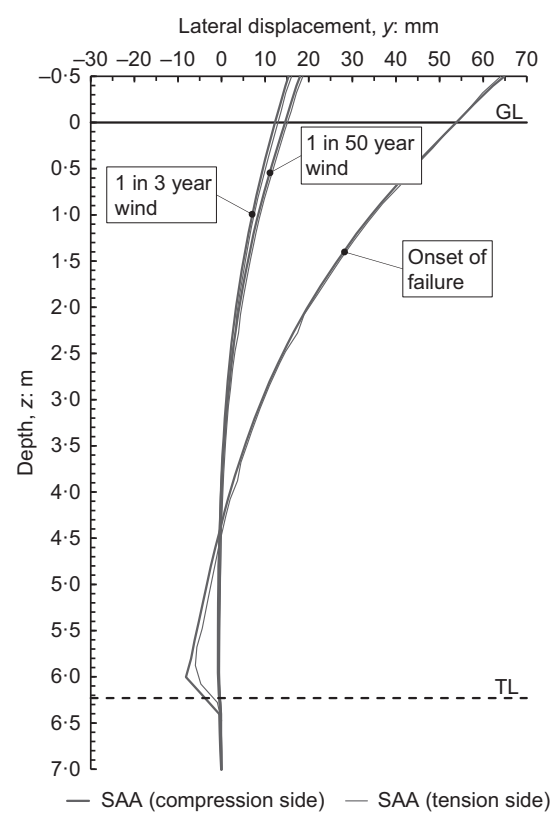

(c)

Fig. 6. Pile deflected shape: (a) STC; (b) TTC; (c) XL-TTC

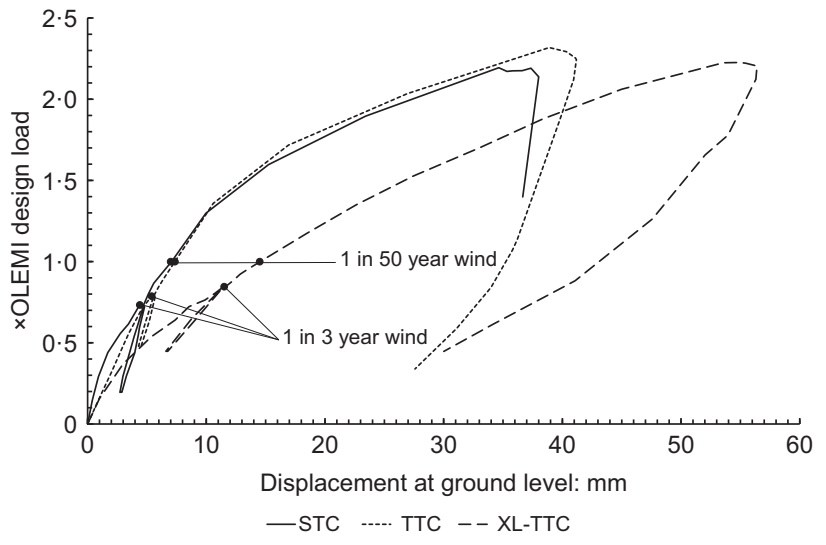

Fig. 7. Pile moment capacity expressed in terms of OLEMI design load

strength (in combination 2, which normally governs the geotechnical design of laterally loaded pile foundations of this type (Powrie et al., 2019)) in ultimate limit state calculations. These equate to a lumped factor of up to 1.82 in a total stress (undrained shear strength) analysis, depending on the relative proportions of permanent and variable load. It is not possible to quantify a corresponding equivalent lumped parameter for an effective stress analysis, owing to the non-linear variation in pile moment capacity with the strength parameter $\phi^{\prime}$. However, in the present case, the foundations are primarily in clay and the response to wind loading events would be expected to be essentially undrained, so analysis may proceed on that basis.

Given the failure load, the equivalent Eurocode 7 characteristic load for each of the foundation piles may be calculated as (the permanent load $-1 \cdot 4$ ) plus (the variable load at failure - 1.82), giving values of $126.6 \mathrm{kNm}$, $271.5 \mathrm{kNm}$ and $576.6 \mathrm{kNm}$ for the STC, TTC and XL-TTC, respectively. These are between 24 and 29\% greater than the OLEMI design loads, with the degree of excess increasing with the size of the structure and the pile length. The associated wire height deflections in the field tests, measured from a datum associated with the equivalent Eurocode 7 characteristic permanent load $(1 / 1 \cdot 4$ or $71 \cdot 4 \%$ of the actual), were $28.4 \mathrm{~mm}$ for the STC, $30.7 \mathrm{~mm}$ for the TTC and $61.9 \mathrm{~mm}$ for the XL-TTC. As before, the calculated wire height deflections do not account for the deformation of the above-ground structure but do include some irrecoverable movement that could be re-set. Hence the results suggest that the partial factors specified in Eurocode 7 for a total stress limit equilibrium calculation based on an undrained shear strength would be sufficient to meet serviceability limit state requirements for the STC and the TTC. This might not be the case for the XL-TTC, whose semi-normalised load-deflection response was rather softer than that of the two smaller structures (Fig. 7). Even neglecting above-ground structural deflection, the equivalent wire height displacement for the XL-TTC on first loading to the Eurocode 7 characteristic load $(29 \%$ greater than the OLEMI design load) was about $40 \%$ greater than the specified serviceability limit.

\section{$\mathrm{p}-\mathrm{y}$ analyses}

A fourth-order polynomial spline (Georgiadis et al., 1992; Smethurst \& Powrie, 2007) was fitted to the lateral pile displacement profiles measured by the tension side SAAs at each load step. (Although the data from the SAAs in each pile were similar, those from the tension side device were less noisy, especially at lower loads.) Fig. 8 shows the results of this fitting method at the 1 in 3 year wind load for each pile. The splines were differentiated four times to derive the net lateral soil resistance per unit length of pile, $p$

$$
\begin{aligned}
& S=\frac{\mathrm{d} y}{\mathrm{~d} x} \\
& M=E_{\mathrm{p}} I_{\mathrm{p}} \frac{\mathrm{d} S}{\mathrm{~d} x}=E_{\mathrm{p}} I_{\mathrm{p}} \frac{\mathrm{d}^{2} y}{\mathrm{~d} x^{2}} \\
& V=\frac{\mathrm{d} M}{\mathrm{~d} x}=E_{\mathrm{p}} I_{\mathrm{p}} \frac{\mathrm{d}^{3} y}{\mathrm{~d} x^{3}}
\end{aligned}
$$




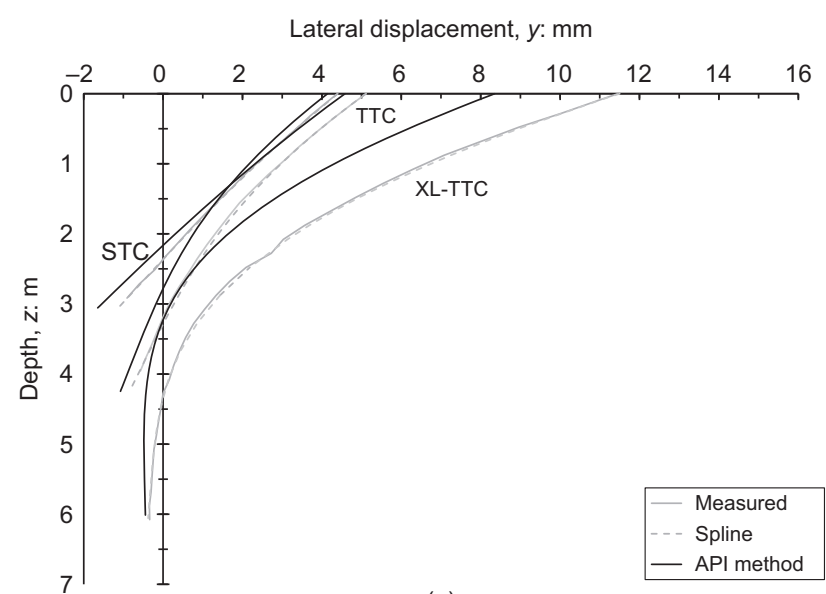

(a)

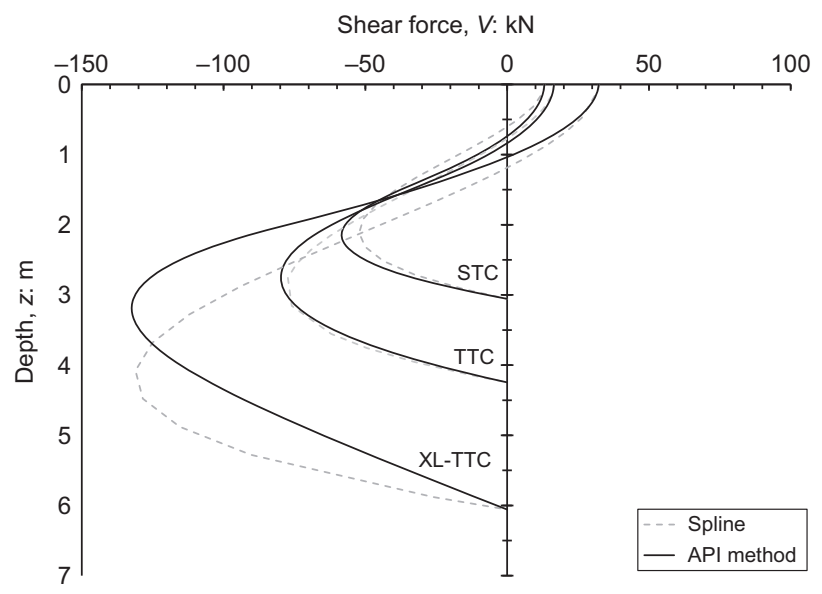

(c)

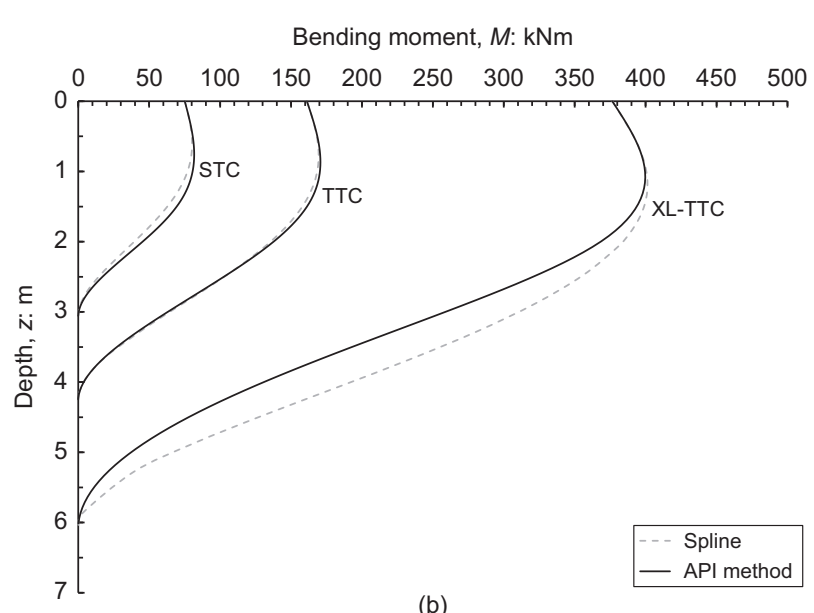

(b)

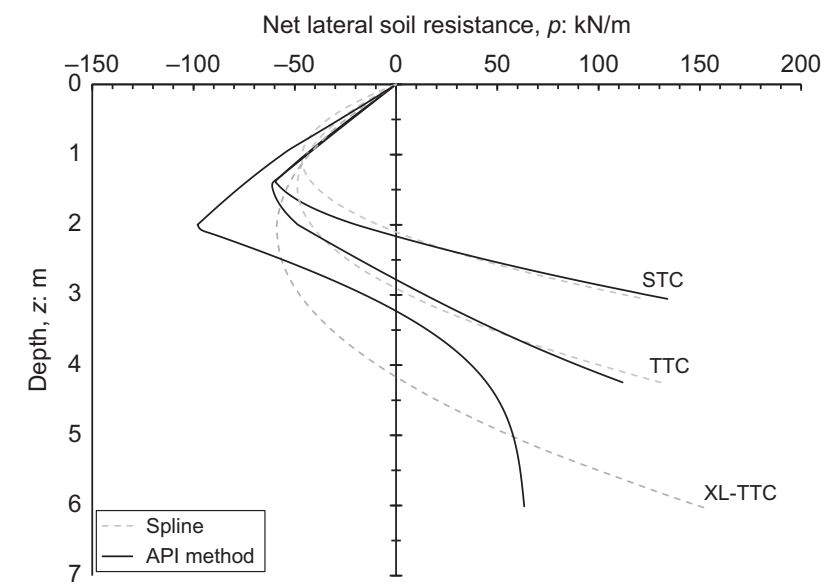

(d)

Fig. 8. Spline fitting and API method results at the 1 in 3 year wind load for each pile type: (a) displacement; (b) bending moment; (c) shear force; (d) net lateral soil resistance

$$
p=\frac{\mathrm{d} V}{\mathrm{~d} x}=E_{\mathrm{p}} I_{\mathrm{p}} \frac{\mathrm{d}^{4} y}{\mathrm{~d} x^{4}}
$$

where $y$ is the lateral pile displacement; $S$ is the pile slope; $M$ is the bending moment; $V$ is the shear force; $x$ is the distance along the pile; and $E_{\mathrm{p}} I_{\mathrm{p}}$ is the pile stiffness, which was $292.4 \times 10^{3} \mathrm{kN} / \mathrm{m}^{2}$ (including the diametrically opposite $60.3 \times 3 \mathrm{~mm}$ steel CHS SAA housings located on both the tension and compression sides of each pile).

$p-y$ curves produced using the net lateral soil resistance derived from equation (6) and lateral pile displacements measured by the tension side SAAs above and below the pivot point are shown in Figs 9 and 10, respectively. As would be expected, the $p-y$ curves exhibit a non-linear soil response (i.e. the stiffness reduces with increasing strain), and the stiffness at a given strain increases with depth. In addition, the $p-y$ curves representing soil below the pile pivot point show a much stiffer response than those located above it. The pivot points developed and moved upwards as the loads were increased, and at the 1 in 3 year wind load were $\sim 2.3 \mathrm{~m}$, $\sim 3.3 \mathrm{~m}$ and $\sim 4.3 \mathrm{~m}$ below ground level for the STC, TTC and XL-TTC piles, respectively.

Although within each group (above and below the pivot) the $p-y$ curves are similar in shape and the increase in stiffness with depth is monotonic, it has not as yet been possible to identify a simple normalisation that would bring all the data within each group onto a single spine curve.
The API method for constructing $p-y$ curves in soils characterised by an undrained shear strength (API, 2014) uses equations established by Matlock (1970) to calculate the net ultimate lateral soil resistance per unit length of pile, $p_{\mathrm{u}}$, and the 'critical' displacement, $y_{\mathrm{c}}$, at which $50 \%$ of this is mobilised

$$
\begin{aligned}
& p_{\mathrm{u}}=\min \left\{\begin{array}{c}
3 s_{\mathrm{u}} D+\sigma_{\mathrm{v}}^{\prime} D+J z s_{\mathrm{u}} \\
9 s_{\mathrm{u}} D
\end{array}\right\} \\
& y_{\mathrm{c}}=2 \cdot 5 \varepsilon_{50} D
\end{aligned}
$$

where $s_{\mathrm{u}}$ is the undrained shear strength; $D$ is the pile diameter; $\sigma_{\mathrm{v}}^{\prime}$ is the vertical effective stress; $J$ is an empirical depth factor; $z$ is the depth below ground level; and $\varepsilon_{50}$ is the strain at $50 \%$ of the maximum stress.

The undrained API method generates $p-y$ curves for short-term quasi-static loading using the 'look-up table' of data of $p / p_{\mathrm{u}}$ as a function of $y / y_{\mathrm{c}}$ given in Table 5 .

The undrained API method was implemented here using the web-based application 'Lateral analysis of piles' (LAP; Doherty, 2017). The idealised undrained shear strength profile defined by equations (2a) and (2b) was adopted in the analyses, with $\gamma_{\text {bulk }}=19 \mathrm{kN} / \mathrm{m}^{3}, J=0.5$ and $\varepsilon_{50}=0.01$, all of which are representative of a firm clay. Results obtained using the undrained API method are shown alongside those from the spline curve fits to the SAA data at the 1 in 3 year wind load for all three piles in Fig. 8. 


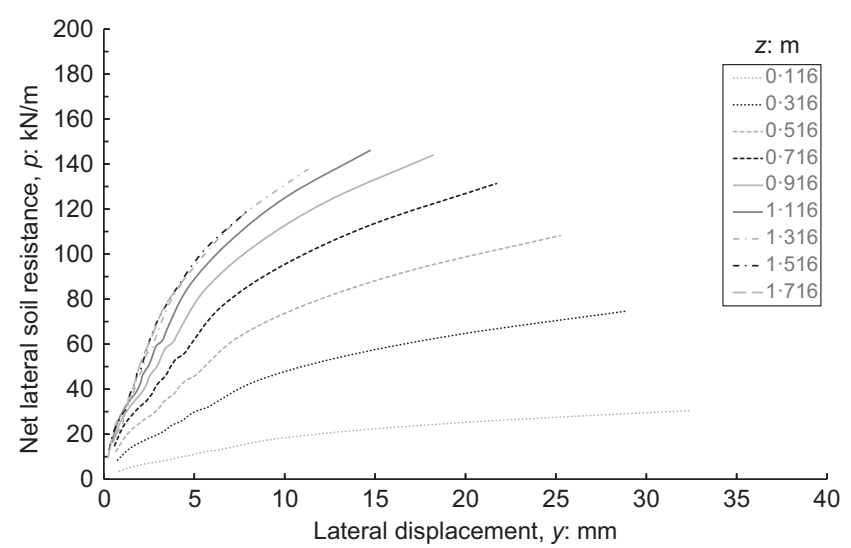

(a)

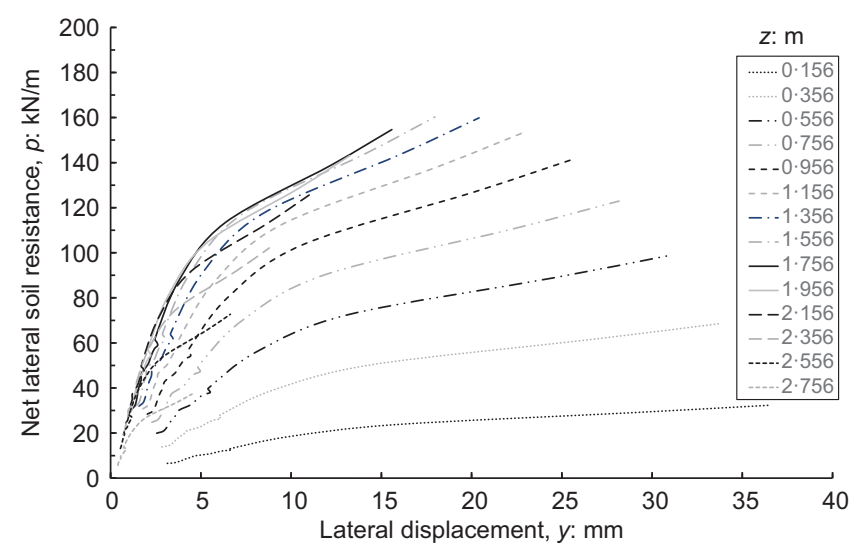

(b)

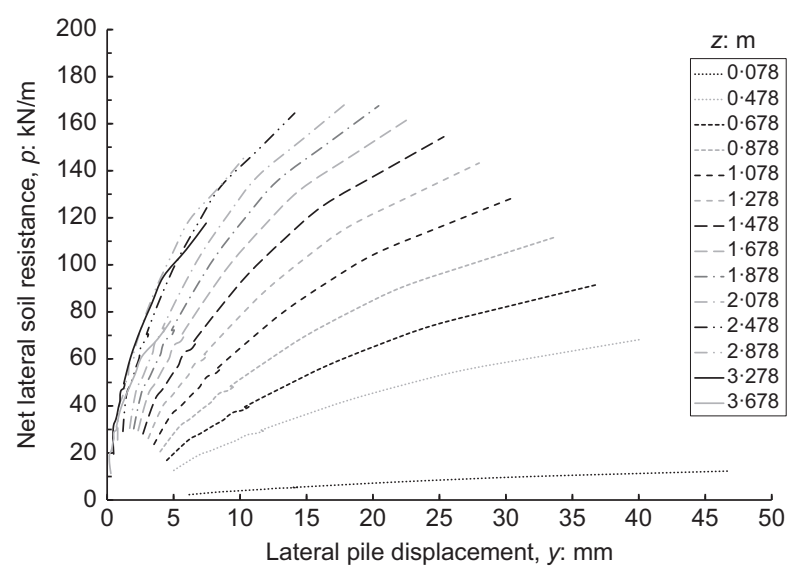

(c)

Fig. 9. $p-y$ curves above pivot point for (a) STC; (b) TTC; (c) XL-TTC

Agreement between the two methods is generally good, especially for the single-track and twin-track cantilevers. Agreement tends to decrease with increasing pile length, and better for the bending moment and shear force than for the displacement and net soil resistance. The worst (and only really poor) fit is for the net lateral soil resistance and the XL-TTC, which according to the API analysis increases to a sharp peak of about $96 \mathrm{kN} / \mathrm{m}$ at $2 \mathrm{~m}$ depth compared with a much more rounded peak of $58 \mathrm{kN} / \mathrm{m}$ at a slightly greater depth from the SAA data. Below $2 \mathrm{~m}$ depth, the API curve is convex upwards rather than convex downwards for the SAA, with net resistances at the toe of about $63 \mathrm{kN} / \mathrm{m}$ and $155 \mathrm{kN} / \mathrm{m}$, respectively. This is probably associated with the underestimation of the rotational component of deformation of the XL-TTC by the API approach, which gives a pivot about $3.3 \mathrm{~m}$ below ground level rather than about $4.5 \mathrm{~m}$ as measured; and illustrates the sensitivity of the calculated net pressure to apparently small changes in relative pile displacement.

\section{CONCLUSIONS}

A series of load tests has been carried out on full-scale piles for railway OLE designed using the empirical OLEMI approach (a derivative of the UIC-ORE method). Three separate piles were installed, designed for different Series 1 OLE support structures; a single-track cantilever (STC), a twin-track cantilever (TTC) and an extra-long large twintrack cantilever (XL-TTC). The tests featured advanced load application and displacement measurement systems, and determined pile deflections under characteristic loads associated with 1 in 3 and 1 in 50 year winds and the ultimate pile capacity, together with the deflected pile shapes.
Displacements at ground level varied between $4.4 \mathrm{~mm}$ and $11.5 \mathrm{~mm}$ under 1 in 3 year wind loading, and between $7 \mathrm{~mm}$ and $14.5 \mathrm{~mm}$ under 1 in 50 year wind loading. Total peak loads achieved before failure of the soil were $224.6 \mathrm{kNm}$ for the STC pile, $474.7 \mathrm{kNm}$ for the TTC and $990 \mathrm{kNm}$ for the XL-TTC. These correspond reasonably consistently to $2 \cdot 2$ times the OLEMI design (characteristic) load in each case.

The STC and TTC foundation piles were essentially 'short', in that they exhibited primarily rotation deformation (with some bending superimposed) at all stages of the load test. The degree of rotation and bending increased, and the point of pile rotation moved upward, with increasing applied load. The XL-TTC foundation pile deformed primarily in bending with the toe of the pile remaining effectively fixed up to the maximum characteristic load ( 1 in 50 year wind), although by failure, rigid body rotation about a point above the toe had also occurred.

The tests have demonstrated the suitability of the OLEMI approach, which gave a consistent equivalent lumped factor on characteristic load of about $2 \cdot 2$, for the large loads associated with the Series 1 OLE. At the OLEMI characteristic load, the wire height deflections of all three structures would have been within the serviceability limit of $50 \mathrm{~mm}$ specified in the relevant current Network Rail standard. The tests also confirmed the likely adequacy of the (less conservative) Eurocode 7 partial factors of 1.3 on variable load and 1.4 on undrained shear strength in a total stress limit equilibrium calculation, at least for the standard (STC and TTC) structures.

$p-y$ curves inferred from the experimental data of displacements by fitting and differentiating fourth-order polynomial splines to the lateral pile displacement profiles 


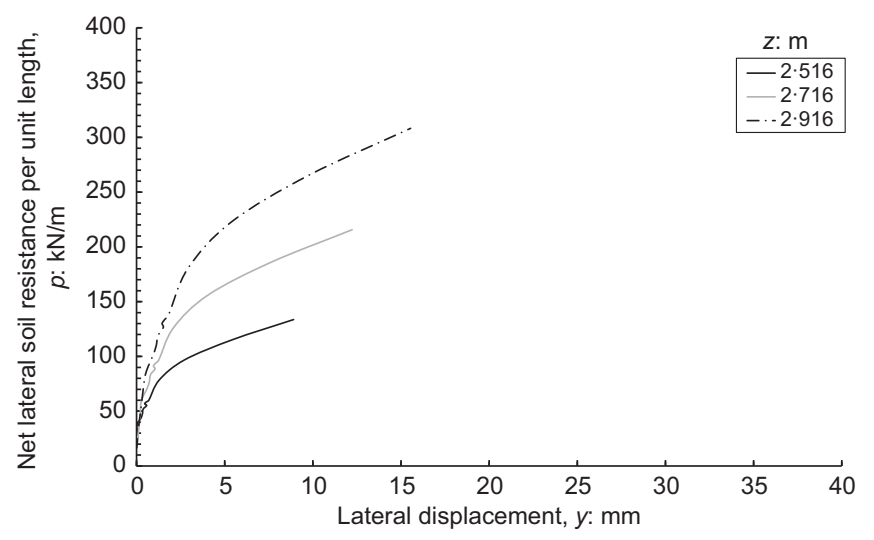

(a)

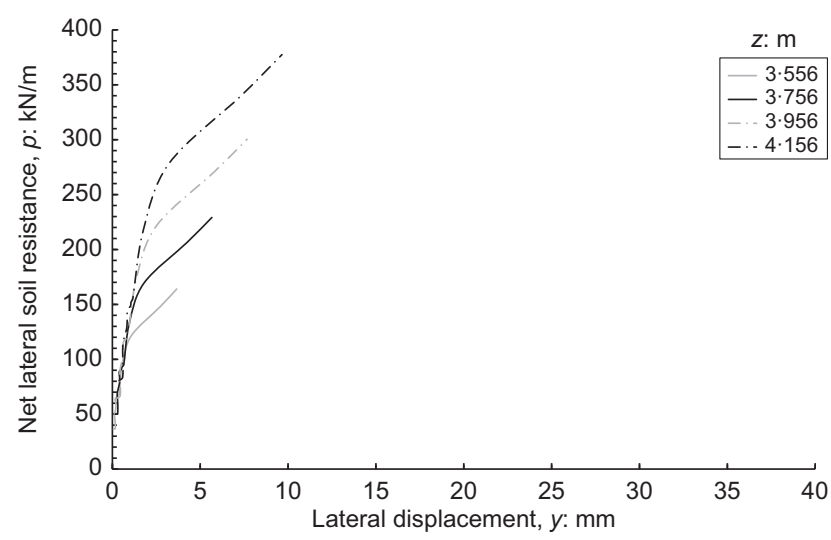

(b)

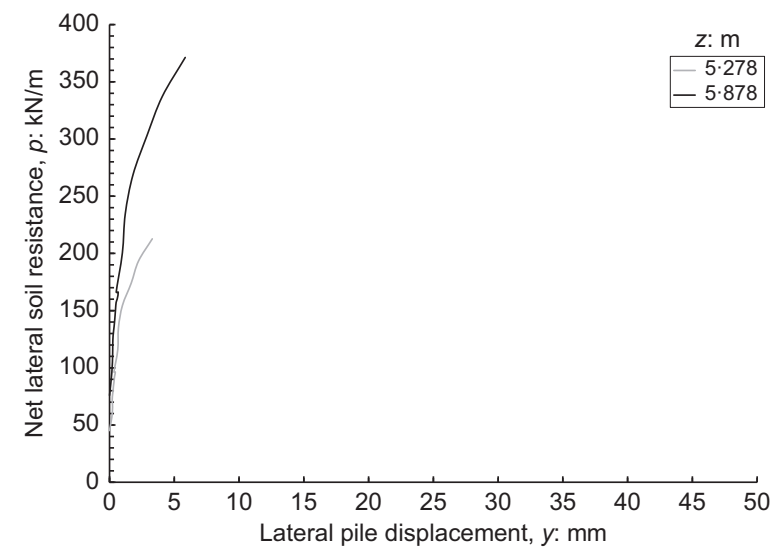

(c)

Fig. 10. $p-y$ curves below pivot point for (a) STC; (b) TTC; (c) XL-TTC

Table 5. API $p-y$ data for short-term static loading in soil characterised by an undrained shear strength, from API (2014)

\begin{tabular}{|c|c|c|c|c|c|c|c|}
\hline $\begin{array}{l}p / p_{\mathrm{u}} \\
y / y_{\mathrm{c}}\end{array}$ & $\begin{array}{l}0 \\
0\end{array}$ & $\begin{array}{l}0 \cdot 23 \\
0 \cdot 1\end{array}$ & $\begin{array}{l}0 \cdot 33 \\
0 \cdot 3\end{array}$ & $\begin{array}{l}0 \cdot 5 \\
1\end{array}$ & $\begin{array}{l}0 \cdot 72 \\
3\end{array}$ & $\begin{array}{l}1 \\
8\end{array}$ & $\begin{array}{l}1 \\
\infty\end{array}$ \\
\hline
\end{tabular}

measured by the SAAs showed consistency in shape at different depths, either above or below the current pivot. However, a suitable normalisation process has not yet been identified.

The distributions with depth of pile lateral displacement, bending moment, shear force and net lateral load obtained by manipulating the splines fitted to the SAA profiles were reasonably close to those calculated using the API method for piles in clay soils. Agreement became less close with increasing pile length (STC $>$ TTC $>$ XL-TTC) and was better for the bending moment and shear force than for the displacement and net soil resistance. The only really poor fit was for the net lateral soil resistance and the XL-TTC probably as a result of the underestimation by the API approach of the pile rotation at depth, combined with the sensitivity of the calculated net pressure to changes in pile displacement.

\section{ACKNOWLEDGEMENTS}

This research was funded by Network Rail through their Strategic Partnership in Future Infrastructure Systems with the University of Southampton. Laboratory testing was conducted at the UKCRIC National Infrastructure Laboratory. The authors acknowledge the contribution of: In Situ Site Investigation to the development and application of the novel system used to instrument the test piles with Shape Array accelerometers; Structural Systems UK for designing the load application system; Cambridge Centre for Smart Infrastructure and Construction for providing technical support with instrumentation; and colleagues Fernando Alvarez Borges, Madhu Murthy, Harvey Skinner, Joel Smethurst, Geoff Watson and Thomas Rye Simmerson for their assistance with aspects of the fieldwork, laboratory testing and data analysis.

\section{APPENDIX. OLEMI DESIGN METHODOLOGY}

$$
\begin{aligned}
M_{\mathrm{B}}= & (M r)_{\mathrm{p}}(1-E p) \\
(M r)_{\mathrm{p}}= & K_{1}^{\prime \prime} e N r+K_{2}^{\prime \prime} \Delta b h^{3} \\
K_{1}^{\prime \prime}= & {\left[0 \cdot 5136-\frac{0 \cdot 175}{0 \cdot 54+(b / e)}\right] } \\
K_{2}^{\prime \prime}= & \left\{2 \cdot 8-\frac{96 \cdot 5}{68 \cdot 5+3 \cdot 375[(N r) / 10 \Delta b e a]^{3}}\right\} \\
\times & \times[1+0 \cdot 45(e / b)]
\end{aligned}
$$

where $M_{\mathrm{B}}$ is the 'moment limit' at ground level; $h$ is the embedded depth of the foundation block (interpreted as the total, i.e. including any ineffective or unconsolidated depth, $\left.h^{\prime}\right) ; e$ is the dimension of the block, viewed on plan, parallel to the overturning force; $b$ is the dimension of the block, viewed on plan, perpendicular to the overturning force; $a$ is the smaller of the two dimensions, $e$ and $b ; N_{\mathrm{r}}$ is the total vertical load (the weight of the block, the mast and 
Table 6. $K$ factors (from UIC-ORE, 1957)

\begin{tabular}{l|c|c|c}
\hline \multirow{2}{*}{ Terrain (topography) } & \multicolumn{3}{|c}{ Direction of pull } \\
\cline { 2 - 4 } & Away from track & \multicolumn{2}{|c}{ Towards track } \\
\cline { 2 - 4 } & & $i>2 \mathrm{~m}$ & $i<2 \mathrm{~m}$ \\
\hline Embankment & 0.85 & 0.95 & $1 \cdot 5$ \\
Level & 1 & 1.3 & 2 \\
Cutting & 1.5 & 1.8 & 2 \\
\hline
\end{tabular}

equipment); $\Delta$ is the 'specific weight' of the soil, 'specific weight' being the term used in UIC-ORE (1957) with the units given as $\mathrm{kg} / \mathrm{m}^{3} ;(1-E p)$ is a correction factor to allow for a depth $h^{\prime}$ of replaced, unconsolidated or otherwise ineffective soil at the surface of the foundation, and may be calculated using equation (5)

$$
(1-E p)=3.44\left[1+\left(\frac{h^{\prime}}{h}\right)^{3}\right]-2.44 \times \sqrt{\left[1+\left(\frac{h^{\prime}}{h}\right)^{2}\right]^{3}}
$$

For a foundation whose cross-section is circular with diameter $D$, $e=b=a=0 \cdot 8 D$.

The full-scale field tests (UIC-ORE, 1957) led to a final equation of the form

$$
M_{\text {ult }}=27.45 K\left(M_{\mathrm{B}}\right)^{2 / 3}
$$

where $M_{\mathrm{ult}}$ in decaNewton-metres (daNm) is the limiting or ultimate moment of resistance of the foundation, measured at ground level, and $K$ is a numerical multiplier (' $K$ factor') that accounts for the slope of the ground and the degree of support from the track (values given in Table 6). $M_{\mathrm{B}}$ is in daNm. $i$ is the distance from the track to the foundation (it is not clear how this is measured, e.g. from centreline to centreline, of from the nearest rail). The numerical constant $27 \cdot 45$ in equation (6) has units of $(\mathrm{daNm})^{1 / 3}$. With $M_{\mathrm{ult}}$ and $M_{\mathrm{B}}$ in $\mathrm{kNm}$, the constant becomes numerically equal to $5 \cdot 194$ and has units of $(\mathrm{kNm})^{1 / 3}$. The allowable or design value of moment at ground level, $M_{\mathrm{GL}}$, is obtained by dividing the value of $M_{\mathrm{ult}}$ given by equation (6) by a factor of 3 . In the OLEMI approach, the weight of the foundation and structure is ignored $\left(N_{\mathrm{r}}=0\right)$, leading to more conservative designs.

\section{NOTATION}

$B$ Skempton pore-water pressure parameter $B$ value in triaxial test

$D$ pile diameter

$E_{\mathrm{p}} I_{\mathrm{p}} \quad$ pile stiffness

$f_{\mathrm{s}}$ sleeve friction resistance

$G_{\mathrm{vh}} \quad$ small-strain shear modulus

$J$ an empirical depth factor

$K$ ORE terrain factor

$K_{0}$ in situ pressure coefficient

$k_{1}$ shear strength gradient of first soil layer

$k_{2} \quad$ shear strength gradient of second soil layer

$M$ bending moment

$M_{\mathrm{B}} \quad$ ORE moment limit at ground level

$M_{\mathrm{GL}}$ cross-track moment at ground level

$M_{\mathrm{ult}}$ ORE ultimate moment of resistance at ground level (daNm)

$N_{k}$ empirical cone factor

$N_{\mathrm{r}}$ ORE total vertical load on foundation

$p$ net lateral soil resistance per unit length of pile

$p_{\mathrm{u}} \quad$ net ultimate lateral soil resistance per unit length of pile

$q_{\mathrm{c}}$ piezocone end resistance

$R_{\mathrm{f}}$ friction ratio

$S$ pile slope

$s_{\mathrm{u}} \quad$ undrained shear strength

$s_{\mathrm{u}, 1} \quad$ undrained shear strength at top of first soil layer

$s_{\mathrm{u}, 2} \quad$ undrained shear strength at top of second soil layer

$u$ pore-water pressure

$V$ shear force $w$ in situ water content

$w_{\text {LL }}$ liquid limit

$w_{\mathrm{PL}}$ plastic limit

$x$ distance along pile

$y$ lateral displacement

$y_{\mathrm{c}} \quad$ displacement at $50 \%$ of maximum stress

$z$ depth below ground level

$z_{1}$ depth below ground level to top of second soil layer

$\gamma_{\text {bulk }}$ in situ bulk unit weight

$\gamma_{\text {dry }}$ in situ dry unit weight

$\varepsilon_{50}$ strain at $50 \%$ of maximum stress

$\sigma_{\mathrm{v}}^{\prime} \quad$ vertical effective stress

$\sigma_{\mathrm{v} 0}$ total vertical stress

$\phi_{\text {crit }}^{\prime} \quad$ critical state angle of shearing resistance

\section{REFERENCES}

API (American Petroleum Institute) (2014). API RP 2A-WSD: API recommended practice for planning, designing and constructing fixed offshore platforms - working stress design, 32nd edn. Washington, DC, USA: American Petroleum Institute.

Atkins (2010). Network electrification - new OLE foundation feasibility, Report No. GEN07, Recommendations for OLE foundations. Atkins.

BH (Buro Happold Engineering) (2015a). NR-working groups for electrification standards typical loading for $G W$ series 1 TTC, 033622-BH (006/010), https://doi.org/10.5258/ SOTON/D1117. Bath, UK: Buro Happold Engineering.

BH (2015b). Series 1 standard STC and TTC rev02, 033677, https://doi.org/10.5258/SOTON/D1117. Bath, UK: Buro Happold Engineering.

BH (2015c). Series 1 critical loading states for XL-TTC structures, 003677-BHP-DN-XL-TTC-001, https://doi.org/10.5258/ SOTON/D1117. Bath, UK: Buro Happold Engineering.

Brinch, H. J. (1961). The ultimate resistance of rigid piles against transversal forces, Bulletin No. 12, pp. 5-9. Copenhagen, Denmark: The Danish Geotechnical Institute.

Broms, B. B. (1964a). Lateral resistance of piles in cohesive soils. J. Soil Mech. Found. Div. 90, No. SM2, 27-63.

Broms, B. B. (1964b). Lateral resistance of piles in cohesionless soils. J. Soil Mech. Found. Div. 90, No. SM3, 123-156.

BSI (1997). BS EN 61773: 1997, IEC 61773: 1996 Overhead lines testing of foundations for structures. British Standards Institution, London, UK.

BSI (2014a). Eurocode 7: Geotechnical design - part 1: general rules. British Standards Institution, London, UK.

BSI (2014b). UK National Annex to Eurocode 7: Geotechnical design - part 1: general rules. British Standards Institution, London, UK.

BSI (2016). BS 1377: 2016 Methods of test for soils for civil engineering purposes. British Standards Institution, London, UK.

Doherty, J. (2017). A web based application for the lateral analysis of pile (LAP) foundations. In Proceedings of the 36th international conference on ocean, offshore and arctic engineering, vol. 9, paper OMAE2017-61600, https://doi.org/10.1115/OMAE2017-61600. New York, NY, USA: American Society for Mechanical Engineers (ASME).

Fleming, W. G. K., Weltman, A. J., Randolph, M. F. \& Elson, W. K. (1994). Piling engineering, 2nd edn. Glasgow, UK: Blackie and Son.

Fleming, W. G. K., Weltman, A. J., Randolph, M. F. \& Elson, W. K. (2009). Piling engineering, 3rd edn. London, UK: Taylor and Francis.

Georgiadis, M., Anagnostopoulos, C. \& Saflekou, S. (1992). Centrifugal testing of laterally loaded piles in sand. Can. Geotech. J. 29, No. 2, 208-216, https://doi.org/10.1139/t92-024.

Krechowiecki-Shaw, C. J. \& Alobaidi, I. M. (2015). An interaction chart design method for Eurocode complaint railway electrification mast foundations. Constr. Build. Mater. 92, 104-110, https://doi.org/10.1016/j.conbuildmat.2014.05.046.

Matlock, H. (1970). Correlations for design of laterally loaded piles in soft clay. Proceedings of the 2nd offshore technology conference, Houston, TX, USA, paper OTC-1204, pp. 577-594, https://doi.org/10.4043/1204-MS. 
Meigh, A. C. (1987). Cone penetration testing: methods and interpretation. London, UK: Construction Industry Research and Information Association/Butterworths.

Mootoosamy, V. K. S., Wiles, G. \& Holder, S. (2015). Network Rail's in-service experience of the ORE method, 133956-IEDREPEOH-000222, https://doi.org/10.5258/SOTON/D1117. London, UK: Network Rail.

NAO (National Audit Office) (2016). Modernising the Great Western railway, Report No. HC 781. London, UK: Department for Transport and Network Rail.

Network Rail (2004). Instruction for the design of overhead line structures, NR/SP/ELP/27215. London, UK: Network Rail.

Powrie, W., Richards, D. J. \& Mootoosamy, V. K. S. (2019). The design of railway overhead line equipment mast foundations. Proc. Insth Civ. Engrs - Geotech. Engng 173, No. 5, 428-447, https://doi.org/10.1680/jgeen.18.00242.

Ramelot, C. \& van Deperre, L. (1950). Les foundations de pylons electriques: leur resistance au renversement, leur stabilite, leur calcul etude experimentale. Comptes rendus des recherches, vol. 2. Brussels, Belgium: Institut pour l'encouragement de la Recherche Scientifique dans l'industrie et Agriculture (in French).
Robertson, P. K. (1990). Soil classification using the cone penetration test. Can. Geotech. J. 27, No. 1, 151-158, https:// doi.org/10.1139/t90-014.

Robertson, P. K. (2009). Interpretation of cone penetration tests - a unified approach. Can. Geotech. J. 46, No. 11, 1337-1355, https://doi.org/10.1139/T09-065.

Robertson, P. K. (2016). Cone penetration test (CPT)-based soil behaviour type (SBT) classification system - an update. Can. Geotech. J. 53, No. 12, 1910-1927, https://doi.org/ 10.1139/cgj-2016-0044.

Robertson, P. K., Campanella, R. G., Gillespie, D. \& Greig, J. (1986). Use of piezometer cone data. In Use of in-situ tests in geotechnical engineering (ed. S. P. Clemence), Geotechnical Special Publication no. 6, pp. 1263-1280. New York, NY, USA: American Society of Civil Engineers.

Smethurst, J. A. \& Powrie, W. (2007). Monitoring and analysis of the bending behaviour of discrete piles used to stabilise a railway embankment. Géotechnique 57, No. 8, 663-677, https:// doi.org/10.1680/geot.2007.57.8.663.

UIC-ORE (1957). Calculation of catenary masts and foundations, Interim Report No. 1. Utrecht, the Netherlands: International Union of Railways/Office for Research and Experiments. 